\title{
Robert Kuśnierz
}

\author{
Akademia Pomorska w Słupsku
}

\section{Przesiedlenia ludności na Ukrainie w latach 1933-1934*}

\begin{abstract}
Abstrakt: Po Wielkim Głodzie, w wyniku którego zmarło co najmniej 3,5 mln osób, bolszewicy stanęli przed problemem braku odpowiedniej liczby ludzi do pracy na roli. Postanowiono wobec tego na tereny najbardziej wyludnione $\mathrm{z}$ powodu głodu sprowadzić chłopów z Rosji i Białorusi oraz przesiedlić rolników z mniej dotkniętych głodem regionów Ukrainy. Akcja nie zakończyła się sukcesem, bowiem większość chłopów sprowadzonych na opustoszałe tereny wróciła z powrotem.
\end{abstract}

Słow a klu c z ow e: przesiedlenia, Wielki Głód, Ukraina, Związek Sowiecki, komunizm.

Abstract: After the Great Famine in Ukraine that killed at least 3.5 million people, the Bolsheviks faced a problem of a lack of resources and people to work on the land. Thus, a decision was made to bring to the most depopulated areas peasants from Russia and Belarus, as well as some farmers from other regions of Ukraine, less affected by the famine. The action did not succeed, as a majority of peasants who were brought to Ukrainian lands devastated by the Holodomor went back to their homes.

Keyw or d s: displacements, Great Famine, Ukraine, Soviet Union, communism.

\footnotetext{
* Powyższy artykuł powstał w ramach projektu Ministerstwa Nauki i Szkolnictwa Wyższego Mobilność Plus (I edycja) w latach 2013-2014, pt. „Ukraina w latach Wielkiej Czystki”, realizowanym w Davis Center for Russian and Eurasian Studies na Harvard University. W tym miejscu składam gorące podziękowania Ministerstwu za sfinansowanie badań. Zarys tematyki omówiłem także w referacie Post-holodomor Population Resettlements to Ukraine (1933-1934), podczas 45. National Convention of Association for Slavic, East European, and Eurasian Studies, która miała miejsce w Bostonie w dniach 21-24 XI 2013 r.
} 
W latach 1932-1933 na Ukrainie miał miejsce olbrzymi głód, który pochłonał według najnowszych danych 3,5-3,9 mln osób ${ }^{1}$. Najbardziej widocznym efektem „bolszewickiej wiosny” 1933 r. było olbrzymie opustoszenie wsi. Rzucały się w oczy każdemu obserwatorowi wyludnienie wsi, zniszczenia domostw i zabudowań gospodarczych, olbrzymia nędza mieszkańców, brak zwierząt hodowlanych itd. Puste chaty i kompletnie opustoszałe wsie jeszcze długo przypominały o tragedii Wielkiego Głodu (hołodomoru). „Wieś ukraińska zrobiła na mnie wrażenie wyludnionej”" - pisał 25 X 1935 r. kierownik Konsulatu Generalnego RP w Kijowie Jan Karszo-Siedlewski. Kierownik placówki wywiadowczej „B.18”, pracujący jako urzędnik konsularny w Kijowie, Władysław Michniewicz w sprawozdaniu ogólnym z podróży z 31 VIII 1935 r. po południowej Ukrainie zrelacjonował, że we wsiach południowych rejonów republiki chaty były bardzo przerzedzone, ok. $1 / 3 \mathrm{z}$ nich stała w ruinach lub ledwo ślady po nich pozostały, jako świadectwo okresu rozkułaczania i głodu ${ }^{3}$.

Wcześniej, w dniach 15-16 VI 1935 r., w podróż po okręgu konsularnym (m.in. odwiedził Białą Cerkiew, Humań, Hajsyn, Bracław, Niemirów, Fastów) wybrał się wicekonsul RP w Kijowie Piotr Kurnicki. 20 VI 1935 r. w relacji z odbytej podróży pisał:

Na ogół widok samej wsi pozostawia przygnębiające wrażenie ze względu na znaczną ilość opuszczonych chat, zrujnowanych zabudowań itp. W rb. widocznie na skutek polecenia władz centralnych, przystapiono powszechnie do rozbierania i niszczenia opuszczonych domów, w rezultacie czego w wielu wsiach, przeważnie na Podolu spotyka się dość często świeże ruiny domów i sterczące jeszcze kominy pieców. W innych wsiach pozostały już tylko puste i porosłe trawa place [...]. We wsiach w najrozmaitszych porach dnia spotyka się stosunkowo małą ilość ludzi. W rozmowie z miejscową ludnością w okolicach pomiędzy Humaniem a Fastowem słyszałem niejednokrotnie zdanie, iż we wsiach tych pozostało obecnie około połowy chałup oraz około jednej trzeciej ludności (rozmówcy z cała pewnością nie byli świadomi, iż rozmawiają z przedstawicielami obcego konsulatu $)^{4}$.

${ }^{1}$ N. Lewczuk, T. Boriak, O. Wolowyna, O. Rudnyćkyj, A. Kowbasiuk, Wtraty miśkoho i silśkoho nacełennia Ukrajiny wnaslidok Hołodomoru w 1932-1934 rr. Nowi ocinky, „Ukrajinśkyj Istorycznyj Żurnał" 2015, nr 4, s. 87; E. Libanowa, Ocinka demograficznych wtrat Ukrajiny wnaslidok hołodomoru 1932-1933 rokiw, w: Hołod 1932-1933 rokiw w Ukrajini. Pryczyny, demograficzni naslidky, prawowa ocinka. Materiaty naukowoji konferenciji, Kyjiw 25-26 weresnia 2008 roku, red. I. Juchnowśkyj, Kyjiw 2009, s. 266-277; S. Kulczycki, Hołodomor. Wielki Głód na Ukrainie w latach 1932-1933 jako ludobójstwo - problem świadomości, Wrocław 2008, s. 364-365.

${ }^{2}$ Centralne Archiwum Wojskowe w Warszawie (dalej: CAW), Oddział II Sztabu Głównego (Generalnego) WP (dalej: Oddz. II SG), I.303.4.3144, k. 1358.

${ }^{3} \mathrm{~W}$ załączeniu do tego raportu Michniewicz dodał kilka zdjęć, które zrobił podczas podróży. Zob. R. Kuśnierz, Unknown Polish Photographs of the Holodomor, „Holodomor Studies” 2010, no. 2, s. 249-255; idem, W świecie stalinowskich zbrodni. Ukraina w latach czystek i terroru (1934-1938) w obserwacjach $i$ analizach MSZ oraz wywiadu wojskowego Drugiej Rzeczypospolitej, Słupsk 2013, s. 412-414.

${ }^{4}$ CAW, Oddz. II SG, I.303.4.3144, k. 938-939; R. Kuśnierz, W świecie stalinowskich zbrodni..., s. $104-105$. 
W wyniku wymarcia całych wsi, aby zrekompensować sobie stratę siły roboczej, bolszewicy zainicjowali akcję przesiedleńczą chłopów, zarówno z Rosji i Białorusi, jak i z samej Ukrainy, na tereny wyludnione podczas głodu. Przesiedlenia pogłodowe rolników miały miejsce po żniwach $1933 \mathrm{r}$. Jednak już w ich trakcie komuniści stanęli przed olbrzymim problemem braku rak do pracy - ludzie albo wymarli, albo czuli się tak osłabieni, że nie byli w stanie produktywnie pracować. Stąd połowiczne rozwiązanie stanowiło wysyłanie robotników i urzędników z miejskich fabryk i urzędów na kołchozowe pola. Praktyka taka była nagminna i odbijała się na funkcjonowaniu różnorakich instytucji. Niektóre pomniejsze zakłady na czas żniw zamykano, gdyż większość ich załogi wysyłano na roboty polowe w kołchozach ${ }^{5}$. Szef referatu „Wschód” Oddziału II Sztabu Głównego kpt. Jerzy Niezbrzycki w oparciu o dane przekazywane mu przez ówczesnego konsula RP w Kijowie Stanisława Sośnickiego przygotował 23 VIII 1933 r. raport o sytuacji na Ukrainie $^{6}$. W nim m.in. wspomniał, że 16 VII 1933 r. kierownictwo Banku Państwowego (ros. Gosbank) w Charkowie otrzymało polecenie wysłania 400 ludzi z oddziału charkowskiego na wieś do robót polowych. Oddział nie był w stanie jednak tego zrealizować i ostatecznie wysłano 200 ludzi, z tym że pozostali, aby wypełnić lukę po nieobecnych, mieli pracować po 10 godzin dziennie bez dni wolnych i urlopów?

Pełniący obowiązki attaché wojskowego RP w Moskwie, kpt. Władysław Harland raportował 2 VIII 1933 r., że z Kijowa na wieś wysłano ponoć aż 50 tys. osób, a z Charkowa jeszcze więcej ${ }^{8}$. Udział nieobeznanych z praca na roli robotników czy urzędników w małym stopniu przyczyniał się do zrealizowania robót rolnych. Harland podkreślał, że wydajność jednego rolnika równała się wydajności 15-20 mieszkańców miast ${ }^{9}$. Stąd efektywnie wypełnić lukę mogli tylko inni chłopi.

Decyzja o przesiedleniach chłopów została podjęta w sierpniu 1933 r. Wtedy przy Radzie Komisarzy Ludowych (RKL) ZSRS utworzony został specjalny urząd - Wszechzwiązkowy Komitet ds. Przesiedleń ${ }^{10}$. Jego zadaniem było koordynowanie i wprowadzanie w życie nowej akcji. Szefem tego komitetu został Aleksandr Murałow ${ }^{11}$. Na Ukrainie Komitet ds. Przesiedleń (przy

${ }^{5}$ Zob. R. Kuśnierz, The Impact of the Great Famine on Ukrainian Cities: Evidence from the Polish Archives, „Harvard Ukrainian Studies” 2008, vol. XXX, no. 1/4, s. 17-18.

${ }^{6}$ Zob. Pomór $w$ „raju bolszewickim”. Gtód na Ukrainie w latach 1932-1933 w świetle polskich dokumentów dyplomatycznych i dokumentów wywiadu, oprac. R. Kuśnierz, Toruń 2008, s. 103-113.

7 Ibidem, s. 109.

${ }^{8}$ R. Kuśnierz, The Impact of the Great Famine..., s. 18; Pomór w „raju bolszewickim”..., s. 100.

${ }^{9}$ R. Kuśnierz, The Impact of the Great Famine..., s. 18; Pomór w „raju bolszewickim”..., s. 99.

${ }^{10}$ Ob obrazowanije Wsiesojuznogo Pieriesielenczieskogo Komitieta pri Sowietie Narodnych Komissarow Sojuza SSR, Postanowlenije CIK i SNK SSSR, „Izwiestija”, 16 VIII 1933.

${ }^{11}$ O naznaczienije tow. Murałowa A.I. priedsiedatielem Wsiesojuznogo Pieriesielenczieskogo Komitieta pri SNK SSSR, Postanowlenije SNK SSSR, „Izwiestija”, 16 VIII 1933. 
Komisariacie Rolnictwa) powołano 23 IX 1933 r. Przy każdym obwodowym zarządzie ziemskim utworzono 5-6-osobowe grupy, które miały zajmować się przybyszami ${ }^{12} .2$ X 1933 r. Komitet Centralny Komunistycznej Partii (bolszewików) Ukrainy [KP(b)U] (oprócz powołanych 23 IX 1933 r. grup przy obwodowych zarządach ziemskich) wyznaczył specjalnych pełnomocników w obwodach, do których mieli przybyć przesiedleńcy ${ }^{13}$.

Do 28 grudnia w 329 eszelonach sprowadzono z Rosji (obwody gorkowski, iwanowski, centralno-czarnoziemny i zachodni) i Białorusi ${ }^{14}$ do Ukraińskiej SRS 21856 rodzin $^{15}$, tj. 117149 osób $^{16}$. W pierwszym kwartale 1934 r. z obwodów kijowskiego, winnickiego i czernihowskiego przesiedlono do obwodów donieckiego, dniepropietrowskiego, odeskiego i charkowskiego co najmniej 15 tys. rodzin, oprócz tego spoza Ukrainy sprowadzono co najmniej 5 tys. rodzin (tysiąc do obwodu donieckiego, tysiąc do odeskiego, 3 tys. do (harkowskiego) ${ }^{17}$.

Tabela 1. Liczba zaplanowanych do przesiedlenia i rzeczywiście przesiedlonych rodzin na Ukrainę w czwartym kwartale 1933 r. i pierwszym kwartale 1934 r. (Dane Wszechzwiązkowego Komitetu ds. Przesiedleń, 17 II 1934 r.) $)^{18}$

\begin{tabular}{|l|c|c|c|}
\hline \multicolumn{1}{|c|}{ Do obwodu } & $\begin{array}{c}\text { Liczba zaplanowanych } \\
\text { gospodarstw do } \\
\text { przesiedlenia }\end{array}$ & $\begin{array}{c}\text { Rzeczywiście } \\
\text { przesiedlono } \\
\text { gospodarstw }\end{array}$ & $\begin{array}{c}\text { Procent } \\
\text { wykonania } \\
\text { planu }\end{array}$ \\
\hline Dniepropietrowskiego & 12800 & 13265 & 104,2 \\
\hline Odeskiego & 11500 & 11854 & 103,1 \\
\hline Charkowskiego & 9500 & 9998 & 105 \\
\hline Donieckiego & 7500 & 7983 & 105,2 \\
\hline Ukraina ogólem & $\mathbf{4 1 3 0 0}$ & $\mathbf{4 3 \mathbf { 1 0 0 }}$ & $\mathbf{1 0 4 , 3}$ \\
\hline
\end{tabular}

Źródło: CDAHOU, f. 1, op. 20, spr. 6584, ark. 73.

${ }^{12}$ Centralnyj Derżawnyj Archiw Hromadśkych Objednań Ukrajiny u Kyjewi (dalej: CDAHOU), f. 1 , op. 6 , spr. 285 , ark. 105.

${ }^{13}$ Ibidem, op. 20, spr. 6392, ark. 21.

14 Białorusini zostali skierowani do obwodu odeskiego.

${ }^{15} \mathrm{~W}$ tym do obwodu dniepropietrowskiego przybyło 6679 rodzin (z obwodu zachodniego w Rosji), do obwodu donieckiego - 3527 rodzin (z obwodu iwanowskiego w Rosji), do obwodu charkowskiego - 4800 rodzin (z obwodu centralno-czarnoziemskiego w Rosji), do obwodu odeskiego - 6750 rodzin (z obwodu gorkowskiego w Rosji - 2120 rodzin i z Białorusi 4630 rodzin). Po podliczeniu tych danych otrzymujemy liczbę przesiedlonych rodzin inną niż podana wyżej (zamiast 21856 jest 21 756). Zob. CDAHOU, op. 20, spr. 6392, ark. 207; Kotektywizacija i hołod 1929-1933, zbirnyk dokumentiw i materialiw, red. S. Kulczyćkyj, Kyjiw 1993, s. 642.

${ }^{16}$ CDAHOU, f. 1, op. 20, spr. 6392, ark. 207; Kotektywizacija i hołod..., s. 642.

17 Szerzej o przesiedleniach pod koniec 1933 r. i na początku 1934 r. zob. R. Kuśnierz, Ukraina w latach kolektywizacji i Wielkiego Głodu (1929-1933), Toruń 2005, s. 198-201.

18 Zob. także nieco inne dane Wydziału Rolnego KC KP(b)U w tab. 4. 
Po przeprowadzeniu akcji przesiedleńczej pod koniec $1933 \mathrm{r}$. i na początku 1934 r., bolszewicy postanowili wysłać na tereny wyludnione kolejna grupę ludzi. 17 X 1934 r. Komitet Centralny WKP(b) i RKL ZSRS podjęli decyzję o przesiedleniu na Ukrainę ok. 21 tys. rodzin. Ponad 3,1 tys. planowano sprowadzić z Rosji, resztę z obwodów kijowskiego, winnickiego i czernihowskiego ${ }^{19}$.

Jak zwykle w takiej sytuacji, władze zorganizowały akcję propagandowa mająca zachęcić ludzi do dobrowolnego przesiedlenia. Używano najchętniej argumentu o wspaniałym ukraińskim czarnoziemie, dzięki któremu chłopi będą mogli uzyskiwać znacznie lepsze zbiory niż w swoich dawnych miejscach zamieszkania. Jadace na Ukrainę eszelony przystrajano zielenia, plakatami, hasłami propagandowymi i naturalnie portretami wodzów. Pełnomocnik Komitetu Centralnego i Centralnej Komisji Kontroli KP(b)U I. Makarenko w lutym 1934 r. informował pierwszego sekretarza Komitetu Centralnego KP(b)U Stanisława Kosiora i szefa RKL USRS Własa Czubara, że ludzie z dużym zaangażowaniem przygotowywali się do przesiedlenia. Kiedy już znaleźli się w wagonach, to w każdym mieli śpiewać i tańczyć, i tylko, według słów Makarenki, gdzieniegdzie na twarzy starych kobiet pojawiała się łezka, gdyż szkoda im było opuszczać ziemię, gdzie żyli ich ojcowie ${ }^{20}$.

Makarenko swój wywód oparł m.in. na listach otrzymywanych od „zadowolonych" rolników. Niejaki kołchoźnik Dmytryjenko z rejonu meńskiego (obwód czernihowski) pisał: „Dom swój wymieniłem na byka, którego wiozę dla swego nowego kołchozu w prezencie. W wagonie jest wygodnie, wyrażam olbrzymią wdzięczność naszemu brygadziście, towarzyszowi Stalinowi, naszej partii, która prowadzi kołchozy drogą leninowską do życia bolszewickiego, a kołchoźnikom zapewnia dostatek" ${ }^{21}$. Natomiast kołchoźnik Łewski z kołchozu „Bolszewik” z rejonu nosowskiego tego samego obwodu odnotował: „Teraz jesteśmy w drodze, otrzymujemy chleb, herbatę, cukier, czekoladę dla dzieci i gorący obiad składający się z dwóch dań. Wszyscy jesteśmy bardzo zadowoleni i bardzo wdzięczni”"22.

Zapewne takie listy zostały napisane i wysłane, gdyż w sowieckiej rzeczywistości każda kampania partii miała „wywoływać żywe oddolne poparcie społeczeństwa”. O ile rzeczywiście chłopi w większości byli zainteresowani wyjazdem na żyzne ziemie, to już sam transport w wielu przypadkach okazywał się nie tak sielankowy, jak ten malowany w propagandzie. Przesiedlenia, tak jak i każda inna kampania komunistyczna, odbywały się w tradycyjnym stylu sowieckim - często bez żadnego przygotowania, chaotycznie, zdarzało się także, że werbowano ludzi na wyjazd, a kiedy ci sprzedawali swój majątek, udawali się na stację kolejowa, tam okazywało się, że nigdzie nie jada.

\footnotetext{
${ }^{19}$ CDAHOU, f. 1 , op. 20, spr. 6583, ark. 188-189.

${ }^{20}$ Ibidem, spr. 6584, ark. 75.

${ }^{21}$ Ibidem.

${ }^{22}$ Ibidem.
} 
10 I 1934 r. dziennikarz „Prawdy” Żyguła informował o wypaczeniach przy akcji przesiedleńczej kołchoźników w obwodzie czernihowskim. Materiał ten przekazano do Komitetu Centralnego KP(b)U z prośbą o akceptację do druku, jednak nie ukazał się. Przedstawiono w nim następujący obraz: 13 XII 1933 r. na stację Czyhynok przybyły z okolicznych wsi 93 rodziny udające się do innych regionów Ukrainy. Osoby te czekały pod gołym niebem na mrozie przez $10 \mathrm{dni}$ na eszelon. Nikt nie zapewnił im pomieszczeń, żywności ani opieki lekarskiej. Dopiero 22 XII 1933 r. pojawił się szef obwodowego komitetu ds. przesiedleń i oznajmił, że żadnego eszelonu nie będzie. Kołchoźnicy nie mieli gdzie wracać - chaty sprzedali, z kołchozem się rozliczyli. Niektórzy z nich udali się do obwodu dniepropietrowskiego, niektórzy do rodzinnych miejscowości. Na stancji pozostały 53 tony przywiezionych przez chłopów kartofli, które zamarzły i nie nadawały się do użytku. Czernihowski obkom 19 XII 1933 r. ograniczył się tylko do stwierdzenia, że takie zachowanie władz lokalnych jest niedopuszczalne ${ }^{23}$.

Ci chłopi, którzy w końcu dotarli na wymarzone czarnoziemy, dość szybko się rozczarowali zastanym widokiem - poniszczonymi przez politykę kolektywizacji gospodarstwami, wyniszczonymi ludźmi i inwentarzem żywym i martwym. Poza tym okazało się, że miejscowa ludność, która przeżyła głód, zaczęła traktować przesiedleńców, zwłaszcza rosyjskich i białoruskich, jako „wysłanników okupantów”, którzy przybyli, aby zagrabić ziemie opustoszałe po tych, którzy zmarli z głodu, a w dalszej kolejności - aby doprowadzić do rusyfikacji wyludnionych wskutek hołodomoru ziem ukraińskich. Stosunek miejscowej ludności do osadników był więc bardzo wrogi. Na każdym kroku starała się im utrudnić w jak największym stopniu życie, podkreślając, że nie sa u siebie. Rosyjscy chłopi przybyli na Dniepropietrowszczyznę skarżyli się, że żyć na Ukrainie się nie da, gdyż miejscowi patrzą na nich jak na okupantów - złodziei ziemi ukraińskiej ${ }^{24}$. Sekretarz komitetu ds. przesiedleń z obwodu donieckiego Morozow informował Murałowa, że z rejonu pokrowskiego w obwodzie donieckim wróciło pod „wpływem kułackiej agitacji i wrogiego nastawienia ludności miejscowej" 19 rodzin. Przesiedleńcom skradziono obuwie, meble, produkty, worki z kartoflami ${ }^{25}$.

Nierzadko dochodziło do zastraszania. We wsi Ołeksandriwka (obwód odeski) na zebranie przesiedleńców wdarła się dziewięcioosobowa grupa, która przepędziła zebranych, wykrzykując przy tym: „Wynoście się kacapy ${ }^{26}$, nigdy nie zaznacie spokoju". We wsi Antoniwka w rejonie piatichackim (obwód dniepropietrowski) sześcioosobowa grupa napadła na przybyszy z Rosji, wznosząc okrzyki: „Bić kacapów, ratować Ukrainę!”27

\footnotetext{
${ }^{23}$ Ibidem, ark. 44-47.

${ }^{24}$ Ibidem, spr. 6585, ark. 73.

${ }^{25}$ Ibidem, spr. 6583, ark. 194.

${ }^{26}$ Pogardliwie o Rosjanach.

${ }^{27}$ CDAHOU, f. 1, op. 20, spr. 6585, ark. 29, 47.
} 
Przypadki okradania i pobić przesiedleńców były na porządku dziennym. We wsi Dykiwka na Odeszczyźnie miejscowe dzieci przy akceptacji swoich nauczycieli systematycznie biły białoruskich rówieśników. 18 III 1934 r. rozbito głowę Białorusince Marii Polewoj, 9 IV 1934 r. ponownie pobito za pomoca kijów $^{28} .19$ VI 1935 r. przewodniczący kochanowskiej rady wiejskiej Strażko w rejonie kehyczewskim w obwodzie charkowskim wraz z brygadzista artelu im. Budionnego, Jakimenkiem pobili kołchoźnika-przesiedleńca Rinasa za to tylko, że czekając na konie z kołchozu, pracował u siebie w przyzagrodowym ogródku. Sprawcy pobicia zostali skazani na sześć miesięcy więzienia ${ }^{29}$. Takie zdarzenia miały miejsce również $\mathrm{w}$ innych miejscowościach i nie należały do rzadkości.

Zdarzały się także zabójstwa przesiedleńców. W styczniu 1934 r. doszło do morderstwa w rejonie nowoukraińskim (obwód odeski) ${ }^{30}$. We wsi Andrijiwka w rejonie kołarowskim (obwód dniepropietrowski) pod koniec stycznia $1934 \mathrm{r}$. wrzucono do studni kobietę, która później zmarła ${ }^{31}$. 9 IV 1934 r. we wsi Fedwal w rejonie znamiańskim (obwód odeski) zabito strzałem z rewolweru Wasilija Barsuka ${ }^{32}$.

Negatywny stosunek do przybyszów przejawiała nie tylko miejscowa ludność, ale także władze lokalne. Nie wydawały przysługującej im żywności i gotówki. Warunki bytowe, za które odpowiadały, było często uragające wszelkim normom. W kołchozie „Komuna Paryska” (obwód doniecki) przesiedlona kołchoźnica mieszkała w karygodnych warunkach - chata była bez drzwi i okien, w środku leżał śnieg. Przesiedleniec Glebow mieszkał w rozwalonym domu, razem ze swoim bydłem, gdyż nie było pomieszczeń dla zwierząt. W kołchozie im. Stalina w tym samym obwodzie dwie rodziny chorowały na tyfus i nie mogły się doczekać opieki medycznej ${ }^{33}$.

Przewodniczacy kołchozu im. Pawło Postyszewa w obwodzie donieckim, Płuczynow oświadczył nowo przybyłym chłopom: „Nie zapraszaliśmy was tutaj, i na czorta jesteście nam potrzebni”34; a przewodniczacy kołchozu im. Kalinina w rejonie dwureczańskim na Charkowszczyźnie wygnał z kancelarii przesiedleńców, którzy prosili o przysługujące im zboże. „Przyjechaliście tutaj marnotrawić chleb - krzyczał - poszli won, nie mam dla was chleba” ${ }^{35}$.

${ }^{28}$ O zajściach w Dykiwce pisała 6 VIII 1934 r. „Prawda”: „Białorusinom zagrodzono dostęp do wody, wobec czego musieli chodzić po nia prawie 2 kilometry. Co noc kradziono im bydło, ptactwo domowe, ubrania, wybijano okna. Miejscowe dzieci biły dzieci przesiedleńców. Taka sytuacja panowała także w innych miejscowościach obwodu”. R. Kuśnierz, Ukraina w latach kolektywizacji..., s. 201.

${ }^{29}$ CDAHOU, f. 1, op. 20, spr. 6776, ark. 97.

${ }^{30}$ Ibidem, spr. 6583, ark. 195.

${ }^{31}$ Ibidem, spr. 6585, ark. 47.

${ }^{32}$ Ibidem, spr. 6584, ark. 126.

${ }^{33}$ Ibidem, spr. 6583, ark. 194.

${ }^{34}$ Ibidem, ark. 195.

${ }^{35}$ Ibidem, spr. 6585, ark. 26. 
W rejonie głobińskim (obwód charkowski) członek zarządu kołchozu „Socialistycznyj Nastup”, Bandura agitował: „Nie potrzebujemy tutaj kacapów, należy ich wypędzić z kołchozu, gdyż przyjechali zjeść chleb, trzeba rozwalić puste chaty, ażeby nie zamieszkali tam kacapy" ${ }^{36}$. We wspomnianej Dykiwce przewodniczacy kołchozu im. Thälmanna i Woroszyłowa, Antonow i Riabczenko oświadczyli Białorusinom: „Wracajcie na Białoruś, zdechniecie tu z głodu”. Wskutek tego 24 rodziny wyjechały ${ }^{37}$.

Pieniądze, który były przekazywane przez władze związkowe i republikańskie na pomoc przybyszom, władze lokalne nierzadko przeznaczały na inne cele - zapłatę za pracę traktorzystów, pokrycie długów kołchozu, zakup materiałów na zasiewy lub po prostu dla siebie ${ }^{38}$. Rosyjscy chłopi przybyli do kołchozu „Droga Lenina” (Szlach Eenina) w obwodzie odeskim skarżyli się, że z 1000 rubli przeznaczonych na ich potrzeby władze kołchozowe przekazały 200. Pozostałe pieniądze poszły na zakup mięsa na obiad dla nich. Mięso co prawda kupiono, ale przesiedleńcy musieli obejść się smakiem, gdyż zostało zjedzone przez członków zarządu kołchozu ${ }^{39}$.

W niektórych miejscowościach przesiedleńcy głodowali, a nawet umierali z powodu braku żywności. Naczelnik dniepropietrowskiego UNKWD Serhij Mironow 14 IX 1934 r. informował pierwszego sekretarza dniepropietrowskiego obwodowego komitetu partyjnego Mendela Chatajewicza, że w wielu wsiach rejonu nowowasyliewskiego zarejestrowano fakty głodowania, puchnięcia z głodu oraz śmierci kołchoźników, szczególnie przesiedleńców - np. we wsi Hanniwka z głodu zmarło małżeństwo przesiedleńców Matwijenko wraz z córką ${ }^{40}$.

O trudnej sytuacji przesiedleńców relacjonowały również polskie placówki konsularne. Piotr Kurnicki 24 II 1934 r. informował szefa referatu „Wschód” Jerzego Niezbrzyckiego:

„Emigrantom” tym przyrzekano złote góry, lokowano ich na miejsca pozostałe po wymarłej ludności i zapewniano, że ze strony miejscowych kołchozów otrzymaja pomoc zarówno w zbożu jak i w żywym inwentarzu. Tymczasem rzeczywistość w najmniejszym nawet stopniu nie odpowiada malowanym perspektywom. Kołchozy zgadzają się dać zboża, ale ze zbiorów roku bieżącego (1934 r.). Inwentarz żywy jest tak wyniszczony, że o przydziale krów lub koni mowy być nawet nie może. Nieliczne wypadki obdarzania „emigrantów” krowami odbywają się w sposób następujący: od jedinolicznikow ${ }^{41}$ zabiera się krowy, konie i świnie za niewykonanie miasozagotowo $k^{42}$

\footnotetext{
${ }^{36}$ Ibidem, ark. 48.

${ }^{37}$ Ibidem, ark. 92.

${ }^{38}$ Zob. ibidem, spr. 6583, ark. 197. Przewodniczący wesełowskiej rady wiejskiej w rejonie zinowiewskim, Bezpalko zmarnotrawił 1400 rubli, które były przeznaczone na remont domów dla przesiedleńców. Ibidem, spr. 6585, ark. 46.

${ }^{39}$ Ibidem, spr. 6584, ark. 87-88.

${ }^{40}$ Ibidem, spr. 6585, ark. 96-97.

${ }^{41}$ Czyli gospodarstw indywidualnych.

${ }^{42}$ Czyli dostaw mięsa.
} 
i sprzedaje się z targu publicznego. Jedynym nabywca jest oczywiście najbliższy kołchoz, który zabiera licytowany inwentarz po cenach wywoławczych. Pieniądze uzyskane ze sprzedaży idą na rzecz państwa tytułem odszkodowania za niewykonanie miasozagotowo ${ }^{43}$.

Wszechzwiąkowy Komitet ds. Przesiedleń codziennie odbierał dużą ilość skarg i zażaleń od chłopów przybyłych na tereny wyludnione. 21 II $1934 \mathrm{r}$. otrzymał 28 listów; dzień później - 45; 23 lutego 1934 r. - 38 ${ }^{44}$. Kołchoźnik Ośmin skarżył się:

W chacie jest zimno [...], dzieci przez to chorują [...]. We wsi szerzy się złodziejstwo, złodzieje sa znani miejscowym organom władzy, ale te nic robia, aby ukrócić proceder. Nie otrzymaliśmy przysługującego nam zboża. Nie mamy nafty i soli [...]. Trzykrotnie jeździliśmy do wydziału politycznego, a ten odmawia pomocy [...]. Konie sa wybiedzone. Trzy padły [...]. Wydział polityczny, rejon i okręg nie pomagaja: przyjada, popatrza, naobiecują i z powrotem wyjeżdżają. Jeśli sytuacja w ciagu miesiąca się nie zmieni będziemy zmuszeni sprzedać cały majątek i wrócić z powrotem ${ }^{45}$.

Rolnik Kuźmin z kołchozu „Prawda” w rejonie starokarańskim w obwodzie donieckim żalił się, że dostał malutką chatę bardziej przypominająca oborę niż mieszkanie. Dziury w niej były takie, że leżące w środku kartofle zamarzały ${ }^{46}$.

Ze względu na złe warunki bytowe, jak i nie najlepsze traktowanie osadników w nowym miejscu zamieszkania przez miejscową ludność, przesiedleńcy na początku żądali, aby odwieziono ich z powrotem do ich dawnych domów. Dochodziło nawet do otwartych protestów przed siedzibami władz lokalnych. W rejonie wołczańskim w obwodzie charkowskim przed siedzibą miejscowego wydziału politycznego protestowało 20 osób, wykrzykując: „Oszukano nas, nikt się z nami nie liczy, wyślijcie nas z powrotem" ${ }^{47}$. Z powodu braku reakcji ze strony władz samowolnie wracali w rodzinne strony. Popularny sposób na obejście przepisów i powrót do dawnych miejsc zamieszkania stanowiło branie fikcyjnych rozwodów. Po rozwodzie mężowie odsyłali swoje byłe już żony do poprzednich miejsc zamieszkania, a następnie sami za nimi się udawali ${ }^{48}$. Konsul RP w Kijowie Stanisław Sośnicki, który w dniach 16-18 VI 1934 r. odbył podróż z Kijowa po Wołyniu i Podolu, po zapoznaniu się bliżej z sytuacja na wsi podkreślał, że sprowadzeni chłopi z innych części Ukrainy i ZSRS wobec zapowiadających się słabych zbiorów zostawiali wszystko i wracali do swoich dawnych miejsc zamieszkania ${ }^{49}$.

\footnotetext{
${ }^{43}$ Pomór $w$ „raju bolszewickim”..., s. 149. Zob. też: ibidem, s. 152, 164.

${ }^{44}$ CDAHOU, f. 1, op. 20, spr. 6583, ark. 196.

45 Ibidem, ark. 194.

${ }^{46}$ Ibidem, ark. 196.

${ }^{47}$ Ibidem, spr. 6585, ark. 25-26.

${ }^{48}$ Zob. ibidem, ark. 28.

${ }^{49}$ Hołodomor 1932-1933. Wielki Głód na Ukrainie w dokumentacji polskiej dyplomacji $i$ wywiadu, red. J.J. Bruski, Warszawa 2008, s. 699.
} 
Istniały też inne przyczyny powrotów. Jedna z nich była tzw. kułacka agitacja, pod którą rozumiano przede wszystkim rozpowszechnianie informacji o głodzie. Drugi sekretarz Komitetu Centralnego KP(b)U Pawło Postyszew w liście z 11 XII 1933 r. do charkowskiego komitetu obwodowego partii pisał: „W punktach przyjmowania przesiedleńców kułackie elementy prowadzą agitację antysowiecka. W rejonie krasnokutskim elementy antysowieckie rozpowszechniły pogłoski o głodzie, trudnej sytuacji, na skutek czego niektórzy chłopi chcieli wracać z powrotem" ${ }^{50}$. Dmytro Ostrowski z wesełowskiej rady wiejskiej na Odeszczyźnie mówił przesiedleńcom, że zbyt długo nie pomieszkaja sobie na Ukrainie i wkrótce umra, że moga spotkać diabłów, którzy duszą ludzi. W rezultacie niektórzy chłopi zdecydowali się na powrót na Białoruśs ${ }^{51}$. Chłopi z rejonu biłokurakińskiego (obwód doniecki) pragnęli wrócić, gdyż kierownictwo kołchozów chciało zabrać ich krowy do robót polowych. W odpowiedzi na to przesiedleńcy zwierzęta sprzedali, oświadczając, że nigdy nie pracowali na krowach przy robotach polowych ${ }^{52}$.

Władze bolszewickie zaniepokoiły się „tendencjami do powrotów” osadników. Komitet Centralny KP(b)U 20 II 1934 r. zobowiązał komitety obwodowe, aby sprawdziły powody powrotu przesiedleńców i ukarały winnych tej sytuacji. Odpowiedzialność za zapewnienie warunków bytowych przybyszom została powierzona sekretarzom obwodowych i rejonowych komitetów partyjnych oraz naczelnikom wydziałów politycznych. Obwodowe władze otrzymały $10 \mathrm{dni}$ na zastosowanie się do wytycznych Komitetu Centralnego i złożenia raportu ${ }^{53}$.

Władze w Odessie wprowadziły w życie otrzymane wskazówki w ciagu tygodnia. 27 II 1934 r. za niewłaściwe podejście (,bezduszne i biurokratyczne”) do nowo przybyłych chłopów przewodniczacy nowoukraińskiego rejonowego komitetu wykonawczego Mariengolc dostał naganę (ros. strogij wygowor). Czterech sekretarzy rejonowych komitetów partii oraz trzech naczelników wydziałów politycznych otrzymało ostrzeżenie, że jeśli nie naprawią błędów i nie podejmą właściwych działań wobec przybyszów z innych regionów, zostana pociagnięci do odpowiedzialności partyjnej ${ }^{54}$.

Wkrótce przykładowo ukarano niektóre osoby bezpośrednio biorace udział w popełnianiu nadużyć. Wśród skazanych znaleźli się zarówno lokalni aktywiści, jak i zwykli chłopi. We wsi Ołeksijiwka rejonu wełykowyskowskiego przewodniczący rady wiejskiej Tynczenko został skazany na trzy lata więzienia za pobicie i bezprawne uwięzienie przesiedleńca Szyłytina ${ }^{55}$. Za wydawanie

${ }^{50}$ CDAHOU, f. 1, op. 20, spr. 6392, k. 138.

${ }^{51}$ Ibidem, spr. 6584, ark. 124.

${ }^{52}$ Ibidem, spr. 6585, k. 25.

${ }^{53}$ Ibidem, op. 6, spr. 338, ark. 81-83.

${ }^{54}$ Ibidem, op. 20, spr. 6584, ark. 121.

${ }_{55}$ Tynczenko w stanie nietrzeźwym wszedł wieczorem do mieszkania Szyłytina. Zobaczył, że ten czytał Ewangelię. Wyrwał mu ją i dotkliwie go pobił, po czym uwięził w zimnej komnacie znajdujacej się w budynku rady wiejskiej. Przesiedleniec został wypuszczony po czterech godzinach przez innych członków rady wiejskiej, którzy się zjawili w budynku. 
zakażonej mąki, wskutek czego czwórka dzieci zmarła, a 20 rodzin zachorowało, brygadzista Iwan Połamar i magazynier Emelian Cybula z artelu im. Kalinina (rejon nowobożański) otrzymali karę odpowiednio dwóch lat więzienia i sześć miesięcy pracy przymusowej. Na osiem lat skazano syna kułaka, Dumanskiego, który wybijał okna w chatach przesiedlonych włościan we wsi Józefpol. W rejonie zinowiewskim aresztowano grupę, na czele której stał kołchoźnik Aleksiejenko, systematycznie dokonująca pobić i zastraszajaca nauczycieli białoruskiej szkoły ${ }^{56}$.

Pomimo podjętych działań tzw. wypaczenia miały miejsce w dalszym ciagu. Sytuacja napływającej ludności została omówiona na posiedzeniu Biura Politycznego Komitetu Centralnego KP(b)U już 6 III 1934 r. W oparciu o raport Aleksandra Murałowa, w którym opisywał karygodne podejście do osadników ${ }^{57}$, politbiuro nakazało obwodowym komitetom partyjnym w Doniecku i Odessie przeprowadzić rozpoznanie opisywanych w raporcie zjawisk i ukarać winnych nadużyć, a o wszystkim powiadomić Komitet Centralny. Oprócz tego władze w Doniecku i Odessie, a także w Dniepropietrowsku i Charkowie otrzymały polecenie sprawdzenia sytuacji przesiedleńców i stworzenia im „jak najlepszych warunków bytowych" 58 .

Obwody, jak wynika z przyjętego dwa miesiące później przez Komitet Centralny $\mathrm{KP}(\mathrm{b}) \mathrm{U}$ postanowienia, niewiele w tej sprawie zrobiły. Wobec tego 4 V 1934 r. ukraiński Komitet Centralny powierzył obwodowym pierwszym sekretarzom partii w Odessie, Doniecku i Charkowie - Jewhenowi Wegerowi, Sarkisowi Sarkisowowi i Ilii Iljinowi, a także naczelnikowi wydziału politycznego Komisariatu Rolnictwa USRS, Ołeksandrowi Asatkinowi, sprawdzenie warunków bytowych i podjęcie odpowiednich działań, ażeby powstrzymać przesiedleńców przed opuszczaniem Ukrainy. Winni wszelkich nadużyć wobec przybyszy mieli zostać pociagnięci do odpowiedzialności partyjnej i karnej. Oprócz tego najbardziej potrzebujące wielodzietne rodziny winny otrzymać w sumie 1000 ton zboża pożyczki, a Komitet Funduszy Towarowych (ros. Komitiet towarnych fondow) zobowiazzano do wydzielenia specjalnie na sprzedaż nowo przybyłym chłopom towarów przemysłowych na sumę $2 \mathrm{mln}$ rubli. Pierwsi zastępcy szefów obwodowych komitetów wykonawczych zostali specjalnymi pełnomocnikami Wszechzwiązkowego Komitetu ds. Przesiedleń. Mieli oni „wzmocnić kierownictwo” akcją przesiedleńczą. W ich gestii było także dbanie o zagospodarowanie się osadników. W obwodzie charkowskim

${ }^{56}$ CDAHOU, op. 20, spr. 6584, ark. 122-124.

${ }^{57}$ Murałow informował ukraiński Komitet Centralny o niedopuszczalnym traktowaniu nowo przybyłych chłopów. W wielu miejscowościach przesiedleńcy nie dostali własnego lokum i zostali przydzieleni do chat miejscowych chłopów. Chaty odremontowane specjalnie dla przesiedleńców przekazywano swoim kołchoźnikom, przybywającym chłopom $\mathrm{z}$ innym regionów pozostawały niewyremontowane domy. $\mathrm{Z}$ obwodów odeskiego i donieckiego wróciło z powodu złego traktowania co najmniej 130 rodzin. Ibidem, spr. 6583, ark. 193.

${ }^{58}$ Ibidem, op. 6, spr. 338, ark. 136-137. 
pełnomocnikiem został Fediajew, odeskim - Karcz, dniepropietrowskim Płys, donieckim - Lifszyc, winnickim - Smolanski, kijowskim - Bohucki, czernihowskim - Hołubiatnykowa ${ }^{59}$.

Decyzje te nie przyczyniły się do zahamowania powrotów. $22 \mathrm{~V} 1934 \mathrm{r}$. Wszechzwiązkowy Komitet ds. Przesiedleń informował władze partyjne, że liczba powracających chłopów nie tylko się nie zmniejsza, ale wprost przeciwnie, ulega zwiększeniu. W tym czasie wyjechało według przybliżonych szacunków ok. 1500 rodzin przesiedleńców, tj. 3,4\% wszystkich niedawno przybyłych osadników ${ }^{60}$. Po zapoznaniu się z tymi danymi, $25 \mathrm{~V} 1934 \mathrm{r}$. Stanisław Kosior i sprawujacy od 28 IV 1934 r. funkcję szefa RKL USRS Panas Lubczenko w imieniu Komitetu Centralnego KP(b)U i RKL USRS zobowiązali odeski, doniecki, dniepropietrowski i charkowski obkomy do „wzmożonej pracy wśród przesiedleńców”, zwłaszcza w tak ważnym momencie zbliżających się żniw ${ }^{61}$. Kilka dni później, w związku ze zwiększającą się liczbą powrotów przesiedleńców, Biuro Polityczne Komitetu Centralnego $\mathrm{KP}(\mathrm{b}) \mathrm{U}$ nakazało wszystkim komitetom obwodowym partii zapewnić każdej rodzinie przesiedleńców mieszkanie. Jeżeli nie dysponowano wystarczająca liczbą wyremontowanych mieszkań, należało wybudować nowe. Oprócz tego obkomy zostały zobowiązane do udzielenia pomocy żywnościowej i furażowej. Jednocześnie trzeba było również zastosować środki ostrzegawcze lub wręcz represyjne. Otóż przesiedleńców należało uświadomić, że w razie gdy zdecydują się na powrót, zostaną ściagnięte $\mathrm{z}$ nich wszelkie koszty, które państwo przeznaczyło na ich sprowadzenie i zagospodarowanie ${ }^{62}$.

Pomimo złego nastawienia miejscowej ludności do obcych, a także tego, że coraz więcej przesiedleńców decydowało się opuszczać przekazane im nowe gospodarstwa, Wszechzwiązkowy Komitet ds. Przesiedleń w marcu 1934 r. planował, że jesienią 1934 r. i w zimie 1934/1935 r. sprowadzi na najbardziej wyludnione tereny na Ukrainie kolejne 60-65 tys. rodzin (ok. 40 tys. miało przyjechać z samej Ukrainy - z obwodów kijowskiego, winnickiego i czernihowskiego). Z tej liczby do obwodu odeskiego i dniepropietrowskiego chciano skierować po $15-20$ tys., charkowskiego - 10 tys. i donieckiego - 15 tys. ${ }^{63}$

Wychodząc z tych założeń, Biuro Polityczne Komitetu Centralnego KP(b)U 26 III 1934 r. poleciło władzom obwodowym w Charkowie, Doniecku, Dniepropietrowsku i Odessie opracowanie listy wolnych chat, które można by przekazać przesiedleńcom. Do 15 IV 1934 r. obwody te miały złożyć przygotowane wnioski o dodatkowe przesiedlenie rolników z innych regionów

\footnotetext{
${ }^{59}$ Ibidem, op. 20, spr. 6585, ark. 35-36.

${ }^{60} \mathrm{~W}$ tym z obwodu charkowskiego wyjechały 553 rodziny, odeskiego - 346, dniepropietrowskiego - 227, donieckiego - 362. Ibidem, ark. 49-50.

${ }^{61}$ Ibidem, ark. 56.

${ }^{62}$ Ibidem, op. 6, spr. 339, ark. 84.

${ }^{63}$ Ibidem, op. 20, spr. 6584, ark. 100.
} 
z rozbiciem na poszczególne tereny. Natomiast władze obwodowe w Kijowie, Winnicy i Czernihowie do tego terminu winny na podstawie ekonomicznej analizy możliwości poszczególnych rejonów i kołchozów podać przybliżone liczby kołchoźników, którzy mieli się udać do innych obwodów ${ }^{64}$.

Obwody przyjmujące przesiedleńców przyklasnęły inicjatywie, choć ich zapotrzebowanie okazało się nieco niższe, niż przewidywały plany Komitetu ds. Przesiedleń. 5 IV 1934 r. prezydium donieckiego obwodowego komitetu wykonawczego podjęło uchwałę o przesiedleniu do obwodu 10 tys. rodzin z innych regionów Związku Sowieckiego. Obwodowe władze w Dniepropietrowsku 12 IV 1934 r. zwróciły się z prośbą do Komitetów Centralnych WKP(b) i KP(b)U o dodatkowe przesiedlenie 5 tys. chłopów nie tylko z USRS, ale też z obwodu zachodniego i innych części RSFRS ${ }^{65}$. Charkowska organizacja partyjna podawała, że w latach 1934-1935 potrzebowała 4778 rodzin, podkreślając przy tym, że dysponowała 6788 wolnymi chatami ${ }^{66}$. Ogółem obwody zgłosiły zapotrzebowanie na 27340 rodzin (zob. tab. 2).

Tabela 2. Zgłoszone wiosną 1934 r. przez obwody USRS zapotrzebowanie na rodziny przesiedleńców

\begin{tabular}{|l|c|}
\hline \multicolumn{1}{|c|}{ Obwód } & $\begin{array}{c}\text { Zgloszone zapotrzebowanie przez obwody } \\
\text { USRS na przesiedlone rodziny }\end{array}$ \\
\hline Dniepropietrowski & 5000 \\
\hline Doniecki & 10000 \\
\hline Odeski & 7000 \\
\hline MASRR & 340 \\
\hline Charkowski & 5000 \\
\hline Ukraina wraz z MASRR ogółem & $\mathbf{2 7 3 4 0}$ \\
\hline
\end{tabular}

Źródło: CDAHOU, f. 1, op. 20, spr. 6585, ark. 3.

Mniej optymistyczne były obwody, które miały oddelegować chłopów. Winnicki obkom 9 IV 1934 r. informował Komitet Centralny KP(b)U, że z obwodu można co najwyżej przesiedlić 2-2,5 tys. rodzin ${ }^{67}$. Z kolei władze w Czernihowie w liście do Komitetu Centralnego KP(b)U z 13 IV 1934 r. podkreśliły, że planowana akcja jest niewskazana, gdyż przeprowadzona rok wcześniej bardzo źle odbiła się na potencjale gospodarczym wielu kołchozów obwodu. Zamiast kołchoźników proponowano zwerbować tylko rodziny indywidualne ${ }^{68}$. Komitet Centralny KP(b)U w odpowiedzi 21 IV 1934 r. napisał, że odrzuca tę prośbę, gdyż „dobrze zorganizowana akcja przesiedleńcza w żaden sposób

\footnotetext{
${ }^{64}$ Ibidem, op. 6, spr. 338, ark. 161.

${ }^{65}$ Ibidem, op. 20, spr. 6584, ark. 107-110; ibidem, ark. 113.

${ }^{66}$ Ibidem, spr. 6585, ark. 42.

${ }^{67}$ Ibidem, spr. 6584, ark. 111.

${ }^{68}$ Ibidem, ark. 118.
} 
nie wpłynie negatywnie na potencjał gospodarczy kołchozów, nie osłabi dyscyplinę pracy i nie zdezorganizuje produkcję" 69 .

Po zapoznaniu się z zapotrzebowaniem obwodów oraz ich możliwościami w dziedzinie zapewnienia względnych warunków bytowych nowym mieszkańcom członkowie Komitetu ds. Przesiedleń, którzy jeszcze w marcu na nowe miejsce osiedlenia planowali sprowadzić 60-65 tys. rodzin, miesiąc później zmienili zdanie i znacznie ograniczyli swoje plany. 27 IV $1934 \mathrm{r}$. Komitet informował Kosiora, że zamierza zwrócić się z prośbą do Komitetu Centralnego WKP(b) o przesiedlenie na Ukrainę 20340 rodzin, 12 tys. z nich miało pochodzić z Rosji ${ }^{70}$.

Plany te jednak nie zostały zrealizowane. W miarę upływu czasu coraz więcej przesiedleńców zdecydowało się opuścić nowe miejsca zamieszkania. 2 VII 1934 r. przewodniczący białoruskiego Centralnego Komitetu Wykonawczego Aleksandr Czerwiakow (biał.: Alaksandr Czarwiakou) informował swojego ukraińskiego odpowiednika, Hryhorija Petrowskiego, że na Białoruś wróciła znaczna część przybyłych na Ukrainę rolników, niektórzy przyszli pieszo. Powracający chłopi często ukrywali się w obawie przed deportacją na Ukrainę ${ }^{71}$.

Do 1 VII 1934 r. z Ukrainy powróciło 13,6\% przesiedleńców, w tym $\mathrm{z}$ obwodu odeskiego $-21,4 \%$, donieckiego $-16,7 \%$, charkowskiego $-8,9 \%$, dniepropietrowskiego $-8,1 \%$ (zob. tab. 3).

Do końca sierpnia $1934 \mathrm{r}$. liczba powracających chłopów prawie się podwoiła. Do tego momentu wyjechało ponad 10 tys. rodzin, zwłaszcza z obwodów odeskiego i dniepropietrowskiego. Niektóre rejony opuścili prawie wszyscy przesiedleńcy (np. krywoozerski w obwodzie odeskim, wasylewski, melitopolski, mahdalinowski i in. w obwodzie dniepropietrowskim) ${ }^{72}$. „Prawda” 6 VIII 1933 r. informowała, że „w ciagu ostatnich miesięcy” z rejonów nowoukraińskiego, zinowiewskiego, znamieńskiego, lubaszewskiego, w obwodzie odeskim, wyjechało $25 \%$ białoruskich przesiedleńców.

Zaniepokojony takim obrotem spraw zastępca komisarza rolnictwa USRS, Grigoriew 2 X 1934 r. sugerował najwyższym władzom ukraińskim omówienie tego problemu na posiedzeniu Biura Politycznego Komitetu Centralnego $\mathrm{KP}(\mathrm{b}) \mathrm{U}$. Proponował m.in. stworzenie specjalnego zbożowego funduszu pomocy w wysokości 100 tys. pudów, a także w październiku zorganizowanie od trzech do pięciu procesów pokazowych przeciwko tym, którzy popełniali przestępstwa i znęcali się nad przesiedleńcami. Przebieg procesów oczywiście miałaby szeroko opisywać prasa ${ }^{73}$. Była to typowa metoda bolszewicka polegająca na tym, że całą winę za nieprzemyślaną źle przygotowaną i realizowaną politykę ponoszą tylko i wyłącznie wybrani na kozłów ofiarnych lokalni aktywiści.

\footnotetext{
69 Ibidem, ark. 120.

${ }^{70}$ Ibidem, spr. 6585, ark. 3.

${ }^{71}$ Ibidem, ark. 81-82.

${ }^{72}$ Ibidem, ark. 104.

${ }^{73}$ Ibidem, ark. 104-107.
} 
Tabela 3. Powrót przesiedleńców z Ukrainy (stan na 1 VII 1934 r.). Dane Ludowego Komisariatu Rolnictwa USRS z 16 VII 1934 r.

\begin{tabular}{|l|l|c|c|c|}
\hline $\begin{array}{c}\text { Obwód/ republika, } \\
\text { z którego przybyli } \\
\text { przesiedleńcy }\end{array}$ & $\begin{array}{c}\text { Obwód, } \\
\text { do którego } \\
\text { przybyli } \\
\text { przesiedleńcy }\end{array}$ & $\begin{array}{c}\text { Liczba prze- } \\
\text { siedlonych } \\
\text { na Ukrainę } \\
\text { rodzin }\end{array}$ & $\begin{array}{c}\text { Liczba } \\
\text { powracają- } \\
\text { cych rodzin }\end{array}$ & $\begin{array}{c}\text { Liczba } \\
\text { powracają- } \\
\text { cych rodzin } \\
\text { w procentach }\end{array}$ \\
\hline Iwanowski (RSFRS) & Doniecki & 3587 & 1121 & 31,9 \\
\hline Czernihowski & Doniecki & 4405 & 216 & 4,8 \\
\hline Gorkowski (RSFRS) & Odeski & 2139 & 835 & 39 \\
\hline Białoruś & Odeski & 4599 & 1269 & 27,5 \\
\hline Kijowski & Odeski & 3017 & 270 & 13,3 \\
\hline Winnicki & Odeski & 8137 & 168 & 5,4 \\
\hline $\begin{array}{l}\text { Centralno-czarnoziemny } \\
\text { (RSFRRS) }\end{array}$ & Charkowski & 2021 & 774 & 9,2 \\
\hline Kijowski & Charkowski & 2058 & 87 & 6,6 \\
\hline Kijowski & Dniepropietrowski & 6826 & 643 & 9,2 \\
\hline Zachodni (RSFRS) & Dniepropietrowski & 4224 & 340 & 8 \\
\hline Czernihowski & Dniepropietrowski & 43100 & 5863 & 13,6 \\
\hline Ogółem & & & & \\
\hline
\end{tabular}

Źródło: CDAHOU, f. 1, op. 20, spr. 6585, ark. 83, 87,

Kampania demaskowania wypaczeń, jak i nawet zaangażowanie NKWD USRS nie zapobiegło masowym powrotom. Wiceszef ukraińskiego NKWD Zinowij Kacnelson 20 X 1934 r. pisał do Kosiora i Postyszewa, że wszystkie wydziały rejonowe podległej mu instytucji otrzymały polecenie prowadzenia destrukcyjnych działań wśród kołchoźników przejawiających tendencje do wyjazdu oraz zastosowania represji wobec inicjatorów i organizatorów takich wyjazdów ${ }^{74}$. Jednak - jak wykazują oficjalne liczby - na niewiele się to zdało. Do 1 X 1934 r. z obwodu donieckiego wyjechało 2920 rodzin przesiedleńców (35,8\%). Do 1 XI 1934 r. obwód dniepropietrowski opuściło 8158 rodzin przesiedleńców (60,9\%), charkowski - 3411 (31,8\%). Do 10 XI 1934 r. z obwodu odeskiego wyjechało 7129 rodzin, tj. 69,5\% ${ }^{75}$. Fiasko akcji przesiedleńczej zostało również odnotowane przez polski konsulat w Kijowie w meldunku z 21 X 1934 r. dla ambasadora RP w Moskwie ${ }^{76}$.

Według danych ${ }^{77}$ Wydziału Rolnego Komitetu Centralnego KP(b)U z 1 IV 1935 r. na nowe miejsca osiedlenia przyjęto 44140 rodzin, z czego 27863 wyjechały, po przerwie powróciło 651 rodzin (zob. tab. 4).

${ }^{74}$ Ibidem, ark. 127-129.

${ }^{75}$ Ibidem, ark. 116-117.

${ }^{76}$ Pomór $w$ „raju bolszewickim”..., s. 170.

77 Dane te nieznacznie się różnią od poprzednio podawanych przez Komitet ds. Przesiedleń oraz Komisariat Rolnictwa USRS. Zob. tab. 1 i 3. 
Tabela 4. Dane Wydziału Rolnego Komitetu Centralnego KP(b)U w sprawie przybycia i odpływu przesiedleńców do obwodów ukraińskich w 1934 r.

\begin{tabular}{|l|c|c|c|}
\hline \multicolumn{1}{|c|}{ Obwód } & $\begin{array}{c}\text { Przyjęto } \\
\text { przesiedleńców } \\
\text { (gospodarstw) }\end{array}$ & $\begin{array}{c}\text { Odplyw } \\
\text { przesiedleńców } \\
\text { (gospodarstw) }\end{array}$ & $\begin{array}{c}\text { Powróciło } \\
\text { (gospodarstw) }\end{array}$ \\
\hline Charkowski & 10683 & 5031 & 49 \\
\hline Dniepropietrowski & 13342 & 9246 & 232 \\
\hline Odeski & 11962 & 9006 & 43 \\
\hline Doniecki & 8153 & 4580 & 327 \\
\hline Lącznie & $\mathbf{4 4 \mathbf { 1 4 0 }}$ & $\mathbf{2 7 8 6 3}$ & $\mathbf{6 5 1}$ \\
\hline
\end{tabular}

Źródło: CDAHOU, f. 1, op. 20, spr. 6618, ark. 73-82.

Jak widzimy, akcja przesiedlania ludności nie zakończyła się sukcesem. Sam Wszechzwiązowy Komitet ds. Przesiedleń istniał do połowy 1936 r. Biuro Polityczne Komitetu Centralnego WKP(b) 8 VII 1936 r. podjęło decyzję o jego likwidacji ${ }^{78}$.

Pomimo niezbyt udanej akcji sprowadzenia ludności na Ukrainę z sąsiednich republik, władze bolszewickie nie dawały za wygrana i postanowiły przesiedlać na opustoszałe tereny tym razem głównie ludność polską i niemiecka. O ile przesiedlenia z 1933 r. i 1934 r. miały przeważnie charakter ekonomiczny, bowiem władzom zależało na sprowadzeniu ludności, to teraz, oprócz nadal aktualnego wymienionego wyżej czynnika, dochodził aspekt o wiele bardziej istotny - polityczny, a mianowicie stopniowe rozwiązywanie „kwestii narodowościowej” w rejonach przygranicznych. W 1935 r. i na początku 1936 r. przeprowadzono kilka etapów deportacji głównie na wschód Ukrainy oraz do Biełbałtkombinatu (głównym jego zadaniem była budowa Kanału Białomorsko-Bałtyckiego). W 1936 r. miała miejsce wywózka ludności polskiej i niemieckiej do Kazachstanu.

\section{Streszczenie}

W latach 1932-1933 na Ukrainie miał miejsce olbrzymi głód, który pochłonął według najnowszych danych co najmniej $3,5 \mathrm{mln}$ osób. W wyniku wymarcia całych wsi, aby zrekompensować sobie stratę siły roboczej, bolszewicy zainicjowali akcję przesiedleńczą chłopów, zarówno z Rosji i Białorusi, jak i z samej Ukrainy, na tereny wyludnione podczas głodu. Decyzja o przesiedleniach chłopów została podjęta w sierpniu 1933 r. Wtedy przy Radzie Komisarzy Ludowych ZSRS utworzony został specjalny urząd - Wszechzwiązkowy Komitet ds. Przesiedleń. Do 28 grudnia sprowadzono z Rosji i Białorusi na Ukrainę 21856 rodzin, tj. 117149 osób. W pierwszym kwartale 1934 r. na Ukrainie przesiedlono 15 tys. rodzin, oprócz tego spoza niej sprowadzono co najmniej 5 tys. rodzin. Po przeprowadzeniu akcji przesiedleńczej bolszewicy postanowili wysłać na tereny wyludnione kolejną grupę ludzi.

${ }^{78}$ Rossijskij Gosudarstwiennyj Archiw Nowiejszej Istorii, f. 89, op. 73, d. 8, 1. 29-31. 
17 X 1934 r. KC WKP(b) i RKL ZSRS podjęły decyzję o przesiedleniu na Ukrainę ok. 21 tys. rodzin, z czego 3,1 tys. z Rosji.

Sprowadzeni, zwłaszcza z Rosji i Białorusi, chłopi byli bardzo źle przyjmowani i traktowani przez miejscowych, którzy widzieli w nich okupantów wysłanych przez Moskwę w celu zasiedlenia ziemi ukraińskiej wyludnionej z powodu głodu. Warunki bytowe na nowym miejscu okazywały się nie najlepsze. Chaty były zniszczone, brakowało produktów żywnościowych, niektórzy przesiedleńcy głodowali. Ze względu na złe warunki bytowe, jak i nie najlepsze traktowanie osadników w nowym miejscu zamieszkania przez miejscową ludność przesiedleńcy zaczęli samodzielnie powracać do poprzednich miejsc zamieszkania. Pomimo złego nastawienia miejscowej ludności do obcych, a także tego, że coraz więcej przesiedleńców decydowało się opuszczać przekazane im gospodarstwa, Wszechzwiązkowy Komitet ds. Przesiedleń w marcu 1934 r. planował, że jesienią 1934 r. i w zimie 1934/1935 r. sprowadzi na najbardziej wyludnione tereny na Ukrainie dodatkowo kolejne 60-65 tys. rodzin, z czego 20-25 tys. miało pochodzić spoza Ukrainy. Plany te jednak nie zostały zrealizowane. W miarę upływu czasu coraz więcej przesiedleńców zdecydowało się opuścić nowe miejsca zamieszkania. Według danych Wydziału Rolnego KC KP(b)U z 1 IV 1935 r. na nowe miejsca osiedlenia przyjęto 44140 rodzin, z czego 27863 wyjechały.

\section{People's displacements in Ukraine in the years 1933-1934}

In 1932-1933 Ukraine was devastated by a great famine which, according to the most recent data, killed at least 3.5 million people. As a result of the extinction of whole villages, the Bolsheviks in order to compensate for the loss of working force initiated the action of displacement of peasants from Russia and Belarus, but also from other parts of Ukraine, to the area most struck by the famine. A decision to bring peasants was made in August 1933, and a special office was established at the Council of People's Commissars of the Soviet Union - the All-Union Committee on Displacement Matters. By 28 December of that year 21,856 families, that is 117,149 people were brought to Ukraine from Russia and Belarus. In the first quarter of 1934,15 thousand families were relocated within Ukraine itself, and at least 5 thousand were brought from outside the country. After the dislocation action the Bolsheviks decided to send another group of ca 21 thousand families to the depopulated area, including 3.1 thousand from Russia.

The new arrivals, especially from Russia and Belarus, were badly accepted and treated by local people who regarded them as occupiers sent by Moscow to take over the Ukrainian lands depopulated by the famine. Living conditions in a new place also were poor. Peasants' huts were destroyed, food was scarce, some of the displaced people suffered famine. And because of those bad conditions and treatment, some of the new settlers began to return home, on their own. Despite this hostile attitude of local people towards the newly arrived, and despite the fact that more and more displaced people decided to go back home, in March 1934 the All-Union Committee on Displacement Matters planned to bring to the most depopulated areas of Ukraine in the autumn of 1934 and the winter of 1934/1935 another 60-65 thousand of families, including 20-25 thousand from outside the country. The plans, however, were not put into effect. As the time passed by, more and more displaced persons decided to leave their new homes. According to the data of the agricultural division of the Central Committee of the Communist Party (Bolsheviks) of Ukraine of 1 April 1935, 44,140 families were brought to new places, but 27,863 decided to return home. 


\section{Bibliografia}

Hołodomor 1932-1933. Wielki Głód na Ukrainie w dokumentacji polskiej dyplomacji i wywiadu, red. J.J. Bruski, Warszawa 2008.

Kotektywizacija i hołod 1929-1933, zbirnyk dokumentiw i materialiw, red. S. Kulczyćkyj, Kyjiw 1993.

Kulczycki S., Hołodomor. Wielki Gtód na Ukrainie w latach 1932-1933 jako ludobójstwo problem świadomości, Wrocław 2008.

Kuśnierz R., The Impact of the Great Famine on Ukrainian Cities: Evidence from the Polish Archives, „Harvard Ukrainian Studies” 2008, vol. XXX, no. 1/4, s. 15-30.

Kuśnierz R., Ukraina w latach kolektywizacji i Wielkiego Gtodu (1929-1933), Toruń 2005.

Kuśnierz R., Unknown Polish Photographs of the Holodomor, „Holodomor Studies” 2010, no. 2 , s. $249-255$.

Kuśnierz R., W świecie stalinowskich zbrodni. Ukraina w latach czystek i terroru (1934-1938) w obserwacjach $i$ analizach MSZ oraz wywiadu wojskowego Drugiej Rzeczypospolitej, Słupsk 2013.

Lewczuk N., Boriak T., Wolowyna O., Rudnyćkyj O., Kowbasiuk A., Wtraty miśkoho i silśkoho nacełennia Ukrajiny wnaslidok Hołodomoru w 1932-1934 rr. Nowi ocinky, „Ukrajinśkyj Istorycznyj Żurnał" 2015, nr 4.

Libanowa E., Ocinka demograficznych wtrat Ukrajiny wnaslidok hotodomoru 1932-1933 rokiw, w: Hołod 1932-1933 rokiw w Ukrajini. Pryczyny, demograficzni naslidky, prawowa ocinka. Materiaty naukowoji konferenciji, Kyjiw 25-26 weresnia 2008 roku, red. I. Juchnowśkyj, Kyjiw 2009, s. 266-277.

Pomór w „raju bolszewickim”. Głód na Ukrainie w latach 1932-1933 w świetle polskich dokumentów dyplomatycznych i dokumentów wywiadu, oprac. R. Kuśnierz, Toruń 2008.

Biogram: Robert Kuśnierz - dr hab., prof. nadzw. Instytutu Historii i Politologii Akademii Pomorskiej w Słupsku. Od 2016 r. dyrektor tegoż Instytutu. Sowietolog, zajmuje się również dyplomacją i wywiadem wojskowym II Rzeczypospolitej. Laureat wielu prestiżowych grantów i stypendiów naukowych (m.in. Harvard University, tygodnika „Polityka”, FNP, różnych programów MNiSW, jak „Mobilność Plus”; „Stypendium dla młodych wybitnych naukowców" i in.). Autor i współautor pięciu książek i kilkudziesięciu tekstów naukowych w polskich i zagranicznych periodykach. E-mail: robert.kusnierz@apsl.edu.pl. 